\title{
BUSINESS GROUPS: \\ PANICS, RUNS, ORGAN BANKS AND ZOMBIE FIRMS
}

\author{
Asli M. Colpan \\ Randall Morck \\ Working Paper 29035 \\ http://www.nber.org/papers/w29035 \\ NATIONAL BUREAU OF ECONOMIC RESEARCH \\ 1050 Massachusetts Avenue \\ Cambridge, MA 02138 \\ July 2021
}

The authors received no funding for this research. The views expressed herein are those of the authors and do not necessarily reflect the views of the National Bureau of Economic Research.

NBER working papers are circulated for discussion and comment purposes. They have not been peer-reviewed or been subject to the review by the NBER Board of Directors that accompanies official NBER publications.

(C) 2021 by Asli M. Colpan and Randall Morck. All rights reserved. Short sections of text, not to exceed two paragraphs, may be quoted without explicit permission provided that full credit, including $\odot$ notice, is given to the source. 
Business Groups: Panics, Runs, Organ Banks and Zombie Firms

Asli M. Colpan and Randall Morck

NBER Working Paper No. 29035

July 2021

JEL No. F65,G01,G21,G23,N2

\begin{abstract}
$\underline{\text { ABSTRACT }}$
Business groups often contain banks or near banks that can protect group firms from economic shocks. A group bank subordinate to other group firms can become an "organ bank" that selflessly bails out distressed group firms and anticipates a government bailout. A group bank subordinating other group firms can extend loans to suppress their risk-taking to default risk, preserving risk-averse low-productivity zombie firms. Actual business groups can fall between these polar cases. Subordinated group banks magnify risk-taking; subordinating banks suppress risk-taking; yet both distortions promote business group firms' survival. Limiting intragroup income and risk shifting, severing banks from business groups, or dismantling business groups may mitigate both distortions; but also limits business groups' internal markets, thought important where external markets work poorly.
\end{abstract}

Asli M. Colpan

Graduate School of Management and

Graduate School of Economics

Kyoto University

Kyoto

Japan

Colpan.asli.2e@kyoto-u.ac.jp

Randall Morck

Faculty of Business

University of Alberta

Edmonton, AB T6G 2R6

CANADA

and NBER

randall.morck@ualberta.ca 


\section{INTRODUCTION}

Business groups, collections of separately incorporated firms, often in multiple industries, often with different but overlapping owners and directors, but under common control, play important roles in most emerging market economies and in the economic histories of most high-income economies (Colpan \& Hikino, 2018a; Jones, 2005; Jones \& Colpan, 2010). In contrast, independent firms now predominate in Britain, the United States, and many other major high-income economies; though business groups remain important in others - notably South Korea and Sweden.

Following Jensen and Meckling (1976), we use "agency" [Latin agens: effective, powerful] to mean effective decision-making. Most business groups are pyramidal (La Porta et al. 1999), vesting agency in an apex firm, which controls other group firms, which control still others, and so on. Whoever controls the apex firm - a business family, tycoon, or professional management team - controls the whole group. Non-pyramidal business groups, prominent in Japan and Korea, are united by webs of individually small intercorporate equity stakes that sum to control blocks. These vest agency with whoever selects group firms' directors: wealthy families in Korea and bankers (for more heavily leveraged group firms) in Japan.

Actual groups can be more complicated. A family might control two firms, each atop a pyramid, or one atop a pyramid and the other on its own. Or a family might control one set of firms via pyramiding and other via director appointments. In such cases, agency falls across firms in proportion to the controlling family's financial interest in each. Thus, for example, if most of the family's wealth is in shares of a pyramid apex company, the family is primarily interested in that firm and agency can be deemed to vest there.

We posit that, if agency vests in a group bank, the group is apt to be run to benefit the bank; and if agency vests in a non-financial group firm, a group bank is apt to be run to benefit that firm. This matters more where "related-party transactions" (shifting assets, 
income and risk between group firms) at non-market "transfer prices" let whoever exercises agency favor some firms over others. Called "tunneling" (Johnson et al., 2000), such transactions are severely limited in some countries (Djankov et al., 2008) because, like transfer pricing by multinationals, they can hide income from regulators and public shareholders (Bertrand et al. 2002). In other countries, bodies of Business Group Law can make tunneling mandatory (Johnson et al., 2000; Hopt, 2015; Belenzon et al., 2018). How effectively such laws are enforced also varies across countries (Djankov et al., 2008).

Tunneling can protect business group firms from external shocks by helping out each other. ${ }^{1}$ Financial economics (Roll, 1988) distinguishes idiosyncratic shocks (affecting only one firm, or a few firms and each perhaps differently) from systemic shocks (affecting all, or most, firms the same way at the same time).

Business groups can buffer idiosyncratic shocks (Faccio, Morck and Yavuz, 2021). For example, an oil price spike boosts energy-producing oil companies' profits, hurts energyhungry aluminum producers' profits, and has little effect on insurance, electronics, and pharmaceuticals firms. An independent aluminum company feels the full shock. An aluminum company in a business group might rely on other group firms to help out. Such help might include artificially reduced premiums from a group insurance company, artificially highly priced aluminum sales to group electronics or pharmaceuticals firms, or artificially highly priced assets sales to a a suddenly cash flush group oil company.

A systemic shock, such as an economy-wide crisis, natural disaster, or political shock hits all or most firms at the same time and in the same way. All hit at the same time, business group firms can hardly help each other out and might seem as vulnerable as independents. However, a business group including a bank (or bank-like financial institution) has yet another

\footnotetext{
1 Khanna and Yafeh (2007) describe business groups' "internal markets" - related-party transactions often at non-market prices - substituting for actual markets distorted or absent due to weak institutions in emerging market economies. Banning tunneling likewise impairs groups' internal markets.
} 
advantage. The bank alone can sometimes buttress all the other firms in the group with a round of new lending. If such loans are not available to independent firms on similar terms, this too is a type of tunneling. If such lending is risky enough to be deemed imprudent, the bank might also be skirting, or even violating, prudential regulations for the good of the group. If the systemic shock reverses quickly, the group emerges unscathed.

Where group firms are protected from shocks, they become individually less risky and often borrow more heavily than do independent firms. This is observed in Canada (Stangeland et al., 1995), Chile (Buchuk et al., 2014), India (Manos et al., 2007), and elsewhere.

However, this protection has limits. If the systemic shock is deep or long enough that other group firms begin defaulting, the group bank can fail. Governments usually bail out distressed banks because fears of bank failures can induce "runs" (Diamond and Dibvig, 1983): Depositors, panicked by rumors a bank is about to close, run to withdraw all their deposits each reasoning that the first in line can retrieve their money but later withdrawers retrieve nothing. Banks lend out much of their depositors' money, keeping only enough on hand to meet normal withdrawal demands, so a big enough run causes any bank to run out of money. A run, even on a perfectly sound bank, can thus become a self-fulfilling prophesy. Runs on one bank tend to cause runs on others, and a wave of bank runs can freeze lending as banks try to build up cash reserves. This freeze can starve healthy firms of credit they need to manage gaps between cash inflows and outflows, causing nonfinancial firms to fail. Vanishing bank savings and escalating unemployment can turn a minor downturn into a deep financial crisis (Kindleberger, 1978; Bernanke, 1983).

To avoid these social costs, governments often rescue banks before runs can happen. Bailout mechanisms range from formal government-backed bank deposit insurance to implicit promises to rescue troubled banks. Ready government bailouts successfully prevent runs, but cause other problems. 
First, a moral hazard problem (Allen et al., 2015) arises: bankers who know distressed banks are bailed out might agree to extend riskier loans. Second, an adverse selection problem (Bruche \& Llobet, 2014) arises: such bailouts effectively subsidize problematically run firms and banks, preventing their displacement by more productive firms and more prudent banks. ${ }^{2}$ To limit both problems, governments impose prudential regulations, regularly updated by the Bank for International Settlements (BIS) in Basel, on banks to limit risky lending. Prudential regulations can contain loopholes, often due to bank and borrower lobbying, and overlook shadow banks (de facto banks organized to avoid being classified as banks).

How all this affects business groups depends on where agency vests. If agency vests elsewhere, the group bank is subordinated and can become what Kato (1957) calls an "organ bank". An organ bank can be pressed to provide selfless support, however imprudent, to the firm of agency and other group firms important to that firm. This transfers the other group firms' losses to the bank, whose bailout in turn socializes those losses. ${ }^{3}$ Moral hazard arises because the subordinated bank managers' decisions about lending prioritize the firm of agency above the bank (or taxpayers) bearing the costs of bad loans. ${ }^{4}$ Adverse selection arises because group firms that would otherwise have failed survive and even prosper.

If agency vests in the group bank, a group bank subordinating other group firms gains by extending loans to those firms, but these can be ordered to damp their risk-taking to protect the bank's earnings. ${ }^{5}$ This reins in moral hazard problems, but overshoots because

\footnotetext{
2 Jones (2005) employs moral hazard and adverse selection as well as transactions costs theory in explaining MNEs (Jones \& Wadhwani 2007). Hauter and Jones (2016) discuss the deep historical roots of moral hazard problems in insurance. See also Jones (2012) on moral hazard in multinational banks, whose subsidiaries can lend recklessly expecting bailouts from the parent bank.

3 Jones (2012) describes how moral hazard problems of imprudent lending by private-sector commercial banks designated as central banks reshaped central banking after the $19^{\text {th }}$ century.

${ }^{4}$ Okazaki and Yokoyama (2001) write "the managers of organ banks [kikan ginko] tended to neglect the interests of depositors and minority shareholders" in prewar Japan.

5 Where agency vests in a group bank, bank directors' career agendas and wealth-maximizing controlling
} 
low-risk low-return undertakings tend not to boost productivity. Caballero et al (2008) call such firms "zombie firms" and associate them with the banks at the centers of Japan's postwar business groups. ${ }^{6}$ Zombie firms staggering on for decades constitute an adverse selection problem.

Severe economic shocks bring moral hazard and adverse selection to the fore, how business groups respond depends on whether the group has a general propensity to tunnel funds to or from the group bank. The remainder of this chapter discusses archetypical examples. These considerations do not amount to a complete theory of business groups, but are, we argue, important factors in many historical settings and in many countries today.

\section{MORAL HAZARD AND ZOMBIE FIRMS}

One polar extreme is agency vesting in the group bank, which subordinates all other group firms to prioritize the bank's interests. Historically, many business groups approximate this to some degree. Business groups often formed during financial crises under surviving banks that seized assets from insolvent borrowers (Colpan and Hikino, 2018b). Belgium's Société Générale de Belgique bank acquired its business group amid banking crises in the late 1830s and 1840s. When industrial firms defaulted, the state-backed bank accumulated their bad loans, writing these off for equity ownership (Becht, 2018; Daems, 1977). Similarly, in Sweden, the Wallenberg and Handelsbanken groups formed when a deflation crisis in 1920 s caused the transfer of corporate shares to the banks (Larsson and Petersson, 2018). The groups further expanded as Ivar Krueger's business group collapsed amid scandal and as the unfolding Great Depression drove more indebted firms into their folds (Sjögren, 1991;

\footnotetext{
shareholders' stockholdings align to prioritize the bank over other group firms. Bank bailouts typically rescue depositors, but not necessarily bank shareholders or top bank executives.

6 Sjögren (1991) highlights how the nature of moral hazard problems depends on the power of banks versus borrowers.
} 
Högfeldt, 2005).

This pattern repeats in other countries and eras. Bank-centered groups formed in Spain after its 2006 crisis, as banks acquired control of financially-troubled industrial companies via debt equity swaps (Cuervo-Cazurra, 2018). After a 1982 debt crisis, Chilean groups emerged by acquiring firms formerly controlled by banks that fell away (Lefort, 2010; Aldunate et al, 2020). Deep pockets can work as well as controlling a solvent bank. As the First World War and a financial crisis badly shook the German economy, the German tycoon Hugo Stinnes, grown rich during World War I, bought up distressed firms at fire sale prices during the financial disruption following defeat (Chisholm, 1922; Lebovics, 1969; Schroter, 2018).

In these groups, agency fell largely onto the banks. A bank sat atop the Société Générale de Belgique business group, which dominated Belgian big business for over a century and a half. ${ }^{7}$ Handelsbanken and the Wallenberg family's Enskilda Bank have played leading roles as Sweden's two largest business groups (Larsson \& Petersson, 2018). Both groups survived to dominate Swedish big business for a century. Group banks subordinating non-financial group firms help all of them survive, but can create and sustain zombie firms.

A detailed example clarifies. Toyo Kogyo (later renamed Mazda Motor Corporation), the maker of Mazda automobiles faced bankruptcy when the 1973 global oil shock dramatically raised petrol prices and disrupted auto manufacturers. Toyo Kogyo survived with the help of its Sumitomo business group, but emerged subordinated to the group's Sumitomo Bank.

The Sumitomo Bank took the lead by extending new loans to Toyo Kogyo that kept the firm solvent and signaled confidence to lenders, suppliers and customers. Sumitomo Bank also parachuted a cadre of its own executives into Toyo Kogyo's board, a common practice in Japanese banking thought to contain moral hazard problems, the propensity of bailouts to

\footnotetext{
7 The group formed in the 1830s and 1840s and survived until its absorption into the French Groupe Suez in 1998.
} 
promote reckless business practices. Sumitomo bank also extended new credit to other Sumitomo group firms, who thenceforth exclusively bought Mazdas, for renewing their auto fleets. Other Sumitomo firms bought some 18,000 Mazdas from 1975 through 1981. Although the Japanese government and Bank of Japan provided no direct funds, Sumitomo Bank's rapid credit extensions were made possible by implicit guarantees of regulatory forbearance and other assistance should the bank require (Pascale \& Rohlen, 1983).

Mazda went on to global success, but many other firms receiving similar group financing injections went on to fill out Japan's ranks of "zombie firms" (Caballero et al., 2008). Distinguishing a bailout to rescue the economy from a bailout to rescue business elites can be difficult. Morck and Nakamura (1999) examine instances of bankers dropped into the boards of distressed Japanese firms receiving debt injections and find a large and statistically significant spike in corporate entertainment expenses (a line item in Japanese annual reports at the time, since made non-mandatory) concurrent with the injections. Citing weak postinjection firm performance, they characterize group banks as propping up, rather than revitalizing, troubled fellow group firms.

One explanation for this is that bankers on their boards are prioritizing debt management, rather than growth. Morck et al. (2000) find a statistically powerful relationship between bank power in the governance of Japanese firms and low-risk corporate strategies and suggest that bankers parachuted into boards to forestall post-bailout recklessness due to moral hazard problems may also suppress profit-enhancing risk-taking. Indeed, creditors' interests are not advanced by debtors' risk-taking, however high the expected returns, if default risk rises even marginally. Large banks appear to have played leading roles in Japan's largest horizontal keiretsu business groups at the time, and pressured their fellow group firms to minimize default risk (Morck \& Nakamura, 1999; Morck, Nakamura \& Shivdasani, 2000). Banks predominating in these groups might thus have fostered risk-avoiding low-productivity "zombie firms". 


\section{MORAL HAZARD AND ORGAN BANKS}

The opposite polar case has agency vested in another group firm, which subordinates a group bank to advance that firm or other affiliated firms important to it. The subordinated bank is pressed to lend generously to those firms, yet cannot intervene to ensure loan repayment. Not run to maximize its own value, the bank sacrifices itself for its group (Okazaki \& Yokoyama, 2001). Kato (1957) coins the term "organ bank" to describe such business group banks. ${ }^{8}$ A subordinated group bank would lend to other group firms as they require, or as ordered to by the group's controlling family or tycoon, yet have little or no influence over those firms' governance. This creates moral hazard problems: those ultimately directing the bank's lending are insulated from the consequences of bad loans. ${ }^{9}$ Other group firms, confident of readily available bailouts from a subservient group bank, see the upside benefits of risk-taking and know the group bank stands ready to absorb the downside. Banks are a special class of firms because they generally are insured by the state, either informally (the central bank is expected to step in to bail out troubled banks) or formally (bank deposits are government insured). Bailouts of banks are considered necessary because households and businesses rely on banks as custodians of savings and providers of credit. Bernanke (1983) shows that the U.S. government's failure to bail out banks early in the 1930 s turned a deepening recession into the Great Depression by allowing the whole banking system to freeze up. Bernanke, in charge of US monetary policy during the 2008 financial crisis, feared a repeat of the events he studied and bailed out US financial institutions early on to forestall

\footnotetext{
8 The parties ultimately controlling the business group rationally subordinate a group bank (organ bank), whose value and survival are less important to their wealth than are other group firms - as when the bank is low in a pyramid, controlled via board appointees rather than shareholdings, or of disproportionately small net worth.

9 In many countries, a failed bank's offices and directors can be prosecuted. The magnitude of this threat depends on the efficiency and political independence of the judiciary. Eisinger (2017 highlights perverse incentives in the US judiciary to explain why no bank officers and directors were prosecuted in the US after the 2008 crisis. South Korea is alleged to have a "too big to jail" problem, in that elites can manipulate the legal system to effectively buy immunity (Choi et al. 2018).
} 
runs on shadow banks.

Government bailouts socialize troubled banks' losses, leaving taxpayers to foot the bill. A business group's organ bank lending selflessly to other group firms and writing off these loans as necessary is likely to become a repository for all the losses of other group firms. If the organ bank then needs a government bailout, all the group firms' losses become taxpayers' liabilities.

Lauven and Levine (2010) find that banks with controlling shareholders are significantly more likely to need bailouts than are independent banks. Morck, Yavuz and Yeung (2011) find financial crises significantly more frequent in countries whose banks are controlled by business families than elsewhere. Organ banks are thus associated with riskier lending, more financial crises, and more bank bailouts. More risk-taking by borrowing firms might be desirable if it resulted in faster adoption of productivity-enhancing new technologies. However, Morck et al. (2011) also report lower productivity growth in economies whose banking systems are more fully controlled by business families. The elevated risk-taking facilitated by organ banks appears to reflect greater moral hazard problems, not bolder innovation.

The twin financial crises Turkey experienced in 2000 and 2001 exemplifies how group banks were giving "bad loans to good friends" (Bakir \& Onis, 2010). Business groups pushed subservient banks for related party loans, the banks being bailout later by the Savings and Deposit Insurance fund. Forbearance by the Treasury and Central Bank let related-party lending substantially exceed regulatory limits (Bakir \& Onis, 2010). The infamous Uzan group case may be an extreme case but highlights the pressure from the controlling shareholder on a subservient group bank (Imarbank) to do more and more lending. The group bank extended $99 \%$ of its credit to other firms in its group. Amid mounting allegations of dubious activities against the group, its controlling shareholder entered politics in 2002, attained $7.2 \%$ support in a national election, and opposed the government. The group firms 
and banks were ultimately seized in 2003 and the group bank was declared bankrupt in 2005 (Cumhuriyet, 27 October 2009; Demirag and Serter, 2003; Oprisk Dergisi, 2014).

Another example - Japan's Suzuki business group in the 1920s - provides a likely underlying causal mechanism. During Japan's late 19th and early 20th century high growth era, most of its larger business groups had affiliated banks. Some business groups - notably the Mitsui, Sumitomo, and Mitsubishi groups - ran their banks along a so-called Scottish banking model: their loans predominantly short-term trade credit, collateralized by inventories, provided to unrelated third parties, not business group member firms. Other business groups - notably the Watanabe, Nakazawa, Matsukata, and Suzuki groups - ran their banks along Kato's (1957) organ bank model: their loans predominantly to finance other group firms' long-term property, plant and equipment investments. Scottish banking model loans were largely arm's-length, liquid, diversified, and relatively low risk; organ banks' loans were largely related party lending, illiquid, undiversified, and high risk. By $1927,94 \%$ of the Nakazawa Bank's loans and 75\% of Jugo Bank's loans were to related-parties (Kato, 1957; Okazaki \& Yokoyama, 2001; Morck \& Nakamura, 2005).

Organ banks accomodated "internal capital market" lending. The Taiwan Bank, founded to develop and industrialize colonial Taiwan and thus used to lending for long-term capital investment, lent primarily Suzuki group firms, which dominated Taiwan. The Suzuki came to control Taiwan Bank's board of directors and direct its policies. By 1927, 72\% of Taiwan bank's loans were to Suzuki group firms (Kakuma, 1975; Lynn \& Rao 1995; Shizume, 2009), yet the Suzuki owned little or none of its stock and thus had no direct financial interest in the bank.

When the Great Kanto Earthquake of 1923, a foreign exchange crisis in 1924 and the Showa Financial Crisis of 1927 shook Japan's economy, groups with organ banks faced financial troubles. Their organ banks could orchestrate new rounds of lending to their member firms, increasing their leverage after each shock. Ultimately, the organ banks were 
left holding illiquid, long-term, non-performing loans collateralized by physical assets, many with earthquake damage. When the politically isolated Suzuki family sought a bailout, the Bank of Japan declined. The Taiwan bank failed and a cascade of defaults brought down the entire Suzuki group. The Bank of Japan intervened to prop up other organ banks, but forced them to diversify their lending. Deprived of ready debt refinancing, every business group with an organ bank broke up. By the end of the 1920s, only groups with Scottish model banks remained, having picked up the pieces of the collapsed organ bank groups (Kato, 1957; Morck \& Nakamura, 2005).

One interpretation of these developments is that that pumping money out of organ banks might necessitate government bailouts of organ banks, suggesting the importance of political influence. The Japanese government of the 1920s was resolutely free-market oriented, and unconditional bailouts of groups or their banks were not politically feasible. While Suzuki's political isolation was unusual, business group controlling families and political elites are more tightly connected in many countries.

\section{MORAL HAZARD AND THE REACH OF THE STATE}

Businesses with political connections can earn higher profits because they can skew government policy to their advantage (Krueger, 1974) and, if their decisions turn out to have been poor, can more readily obtain government bailouts (Faccio et al., 2006). The controlling families of large business groups are likely to have exceptionally strong political influence (Schneider, 2010). Morck and Yeung posit the following as important to the reliability of business-government favor trading relationships.

First, many countries' business and political elites are from the same handful of powerful families (Faccio, 2006). Top officials whose families control large business groups may conflate the national interest with their families' interests.

Second, if enhanced stability makes business groups long-term survivors, they become 
preferred favor trading partners for corrupt government officials. Axelrod (1984) shows that repeated interactions build trust and allow easier cooperation. An official owed a favor by a business group's controlling family can rely on the family's longevity. In contrast, an independent firm's CEO, in office for perhaps 5 years, cannot be relied on to the same extent to return favors.

Third, Bernheim and Whinston (1990) show that multiple simultaneous games work as well as repeated games. A business group can orchestrate favor trading between politicians and many group firms. A favor to one firm can be returned by a different firm in the group; a failure to repay a favor owed one firm can be punished by another group firm. In contrast, an independent firm's interaction with an official is a one-to-one bargaining situation.

Fourth, if most big businesses belong to one business group or another, politicians can "do a deal with big business" by phoning a handful of tycoons. The tycoons controlling these business groups thus have "economies of scale" in influence. Government officials can more broadly influence business decisions by calling in favors owed by a family controlling a larger business group. Likewise, a family with a business group containing more corporations can use its political influence to benefit more corporations. Moreover, restricting favor-trading to a smaller number of people makes cooperation easier to monitor (Olson, 1965).

Fifth, the families that control large business groups are wealthy and powerful enough to initiate favor trading by bestowing a valuable boom upon a key official. Independent firms, especially new entrants, must beg for officials' favors by promising future repayment.

Sixth, political favor-trading is technically illegal in most countries, and so must be discrete. Marcus and Hall (1992, p. 131) conclude "the power of dynastic wealth is its power to be conspiratorial, to make secret deals, that is, to pull together resources from across various social and institutional spheres to pursue a single aim."

The difference between socially enlightened business government partnerships and corruption can be as obscure as the motives in bank bailouts, but carries more political ballast. 
Perspectives on the social contribution of the exceptionally tight links that can arise between business groups and governments span this full range.

Transparency international ranks Sweden as one of the world's least corrupt countries; yet for most of the $20^{\text {th }}$ century, three large business groups encompassed most of its big business sector since the 1920s (Högfeldt, 2005). Over the subsequent decades, the business groups and successive Social Democratic governments learned to appreciate each other. Social Democratic prime ministers could 'do a deal" with big business via a few phone calls and the business groups' member firms learned to prosper off subsidies and industrial policy programs, protected from upstart competitors by dense regulations and high taxes. Like Japan, Sweden prospered as a highly stable economy. However, Sweden has no large firms founded later than the 1960s and some Swedish economists (Hogfeldt, 2005) worry it too has a zombie firm problem. Other European countries in which business groups loom large emulated Swedish business-government cooperation to varying degrees and lowproductivity zombie firms are now worrying policy makers across Europe (McGowan et al., 2018).

On the other hand, Turkey's largest businesses prospered through World War II by gaining preferred access to tightly government-restricted foreign exchange. For example, firms in the Koç group, Turkey's largest, resold imported goods at substantial black-market markups. Its founder, Vehbi Koç, $(1983$, p. 62) lamented how their "morality deteriorated as an organization ...and knowingly or unknowingly [was] stained in front of the customer". Nonetheless, even government procurers, circumventing their own foreign exchange controls, bought trucks and other scarce imports from Koç firms. These black-market profits later helped the group expand (Colpan \& Jones, 2013; 2016).

Tight business-government linkages can even salvage organ-bank-financed groups amid major crises. An organ bank, in bailing out other group firms, assumes all their losses. Thus, banks controlled by other firms or by business families make riskier loans than do 
comparable independent banks (Laeven \& Levine, 2009; Silva, 2018). La Porta, Lopez-deSilanes and Zamarripa (2003) report that intragroup loans are more likely to default and, when they do, have lower recovery rates than unrelated ones. Moreover, banking systems more fully controlled by business families accumulate more non-performing loans and are more prone to banking crises (Morck, Yavuz \& Yeung, 2011). Just as tighter political connections that render bailouts likelier cause riskier lending and group expansion, bigger groups financed with riskier debt necessitate renewed group investment in political connections (Khanna \& Yafeh, 2007; Morck, Yavuz \& Yeung, 2011). And, during financial crises, banks and firms outside groups might favor firms in business groups because these considerations make them safer to deal with (Kuppuswamy \& Villalonga, 2010; The Boston Consulting Group, 2012).

\section{ADVERSE SELECTION AND THE REACH OF THE STATE}

When a sorting mechanism moves assets to lower, rather than higher, productivity uses, an adverse selection problem exists. During a crisis, business group firms can seem a haven of stability. Thus, Castaneda (2007) describes how Mexican business groups sustaining recovery after the 1995 crisis. That crises shift more of the economy's assets into such safe havens seems laudable. However, when bailouts and politics call the shots, the most productive firms need not survive and the survivors need not end up controlled by the most innovative people.

Thus, Morck, Yavuz and Yeung (2011) show an economy's capital allocation across industries to be significantly less efficient where the banking system is more fully controlled by business families. Indeed, the tighter the business-government connections, the more political, rather than economic, forces become. Thus, during the 2008 crisis, Turkish stateowned banks lent US\$750 million to a holding company controlled by a close friend of the Prime Minister to finance its purchase a large media group (Hürriyet, 24 April 2008, Bakir \& Onis, 2010). 
Extraordinary tight business-government connections prevail in much of the world. North et al. (2013) attribute this to a "limited access" order, in which the police and courts are only accessible to a tiny elite, with most small businesses and most people living in a quasiillegal grey market economy. In a limited access order, government and business groups become "vertically integrated" because only businesses controlled by the elite can depend on the police and courts to enforce contracts, protect property rights, and deter criminal and official predation. Haber (2013) sees such a vertical integration throughout Latin America.

Limited access orders are associated with authoritarian governments and incomplete democracies. Open access orders, which characterize high-income mature democracies, enforce agreements, protect property, and deter criminal and official predation, for their whole populations, not just tiny elites. This view attributes the institutional voids, which Khanna and Yafeh (2007) describe business groups bridging, to a limited access order, a more fundamental institutional deficiency. Thus, business groups are more prevalent where institutional voids are larger, which is where open access order institutions are less developed (Fogel, 2007; Schneider, 2010).

As an economy develops and access opens, this vertical integration of big business and political elites can snap. Previously privileged access may vanish after a change in government. Indeed, business groups run by excessively domineering elites can become a "sector that loses favor with the authorities because of its excessive influence" (Khanna \& Yafeh, 2007).

The Daewoo business group, founded in 1967, when General Park Chung-hee ruled South Korea, survived the 1987 transition to democracy; but needed bailouts amid the 1997 Asian financial crisis. Daewoo firms' debts averaged 3.4 times equity. High as this was, the comparably large Hyundai business group's firms carried debts averaging 4.4 times equity (Corsetti, Pesenti \& Roubini, 1999). Korean business groups could not include banks, but both groups contained non-bank financial institutions that served as organ banks. Hyundai's 
controlling family accepted government policies. Daewoo's patriarch, Kim Woo Choong, whose father had mentored General Park, resented the government's impudence and even (briefly) sought the presidency himself. When the crisis hit in 1997, with no bailout on offer, the Daewoo group collapsed much as the Suzuki group had in 1920s Japan (Chung, Byun \& Young, 2019; Oh, 1999). The government intervened to stabilize all other major business groups, including Hyundai.

\section{DECAPITATION ${ }^{10}$}

Crises deep enough to delegitimize-big business can strengthen the state and motivate politicians to let groups fail, or even to actively break up groups. This is best illustrated in the destruction of US business groups in the 1930s. Business groups had arisen as the US industrialized in the decades after its 1860s civil war. Because US courts then held that Common Law prohibited corporations from owning stock in other corporations, these were organized as voting trusts, rather than pyramids. Trusts became controversial for accumulating monopoly power during a wave of populism and the Unites States became the first country to introduce anti-monopoly legislation - the 1890 Sherman Antitrust Law. Anti-monopoly laws in the US are still called "antitrust" laws, though voting trusts quickly disappeared. Business lobbying prompted state governments to pass legislation allowing corporations to own shares in other corporations, and the trusts restructured into pyramidal groups, which (not being organized around trusts) were thought immune to anti-trust laws. By the late 1920s, pyramidal business group firms comprised the majority of assets on the New York Stock Exchange (Kandel et al. 2019).

Great inequality that built up from the 1890s to the 1920s was not a huge issue as long as the Roaring Twenties broadened middle class prosperity. But the Crash of 1929 and the Great Depression created an unprecedented economic and political crisis.

\footnotetext{
10 In movies, zombies are killed by cutting off their heads.
} 
The magnitude of that crisis remains unmatched. Unemployment rose to $25 \%$ and cut industrial production by some $40 \%$. Millions who had thought themselves middle class lost their jobs, homes, businesses and farms. Millions lost their life savings as a third of all banks failed, their depositors losing everything, and the Dow Jones Industrial Average collapsed to less than $10 \%$ of its pre-crisis high. Shanty towns arose around American cities. Faith in free market economics, and even in democracy, faltered. Americans packed Madison Square Gardens to attend Communist and National Socialist rallies (Morck\& Yeung, 2009; New York Times, 1936; 1939).

Franklin Delano Roosevelt and the Democratic Party swept the 1933 election. Roosevelt promised a New Deal - a reshuffling of the cards to start a fairer version of free market democracy. Advised by a "brain trust" of academics, including Columbia Law school professor Adolf Berle and Harvard economist Gardiner Means, Roosevelt launched a series of reforms designed to break up business groups (Morck, 2005). Popular sentiment had turned so far against business elites, that these measures were invulnerable to lobbying. Indeed, lobbying proved counterproductive as the undue power of business elites became a major reason for breaking up large business groups.

Whether or not corporations could own shares in other corporations was delegated to state governments, so the brain trust devised an arsenal of new Federal weapons. Taxes on dividends paid by one corporation to another, levied at rapidly increasing rates in each successive Federal budget, soon made pyramidal groups profoundly tax disadvantaged. The Public Utilities Holding Company Act of 1933 banned pyramids over two tiers high in public utilities, including the 1920s high tech electivity and telephone networks sectors. The GlassSteagall Act of 1933 forced commercial banks to divest their shares in other companies, effectively decapitating the Morgan bank off the Morgan group, at the time the largest and most diversified business group in America. The Investments Companies Act of 1940, by subjecting corporations whose assets are primarily shares in other corporations to mutual 
fund regulations that forbid interference in those corporations' management decisions, except through shareholder proxy solicitation, effectively shutting off a final possible escape route. By the 1950s, business groups were largely gone (Hikino \& Bucheli, 2018; Kandel et al., 2019).

Only echoes of business groups remained. Conglomerates arose in the 1950s and 1960s, but took the form of a single company with operating assets in multiple industries. Venture capital funds and private equity funds arose in the 1980s and 1990s to control multiple unlisted companies; but usually with the ultimate aim of selling their holdings into public equity markets (Collis et al, 2018). Mutual fund companies often manage blocks of stock in many firms, but are subject to Investment Company Act limitations on interference in management. Warren Buffet's Berkshire Hathaway, which fully owns some companies and holds public equity blocks in others, is a hybrid of a private equity fund, a mutual fund, and a conglomerate. None of these structures remotely rival the power of America's largest 1920s pyramidal business groups.

Only two other countries have successfully legislated away business groups. Japan broke up its pyramidal business groups in the late 1940s while under American military occupation, its economic administration delegated to New Deal reformers. Fifty-six families running ten zaibatsu and 83 holding companies were targeted. To create a "democratized" economy, the US occupation government transferred the controlling families' shares and intercorporate shareholders in these firms to the Holding Companies Liquidation Commission, which redistributed them through public sales. This permanently marginalized the elite zaibatsu families (Miyajima \& Kawamoto, 2010; Lincoln \& Shimotani, 2010).

After the zaibatsu dissolution, a brief period of dispersed shareholding ensued. In the 1950s and 1960s, some widely held ex-zaibatsu affiliates became targets of hostile takeover toehold bids. To block takeovers, their managers erected a defense mechanism: webs of individually small privately cross-shareholdings that summed to control blocks and whose 
cross-dividends largely cancelled (Lincoln \& Shimotani, 2010). Thus arose a new business group structure, the "kigyo shudan" (ie. horizontal keiretsu).

Israel's economy was badly shaken during the 2008 global financial crisis. In 2007, firms belonging to 30 business groups comprised $75 \%$ of the value of the Tel Aviv Stock exchange. These had expanded, to a large part, by acquiring control blocks in state-owned enterprises privatized after the Labor Party lost power and free-market reformers gained ascendency. The business groups were highly diversified and individual group firms were highly leveraged. When the 2008 crisis hit, industrial diversification was no salvation and the groups' controlling families lobbied aggressively for bailouts. In response to the intensive bout of lobbying, the government enacted the 2013 Law for Promotion of Competition and Reduction of Concentration. This echoed several of the American New Deal anti-business group reforms: It limited pyramidal business groups to two tiers of corporations controlling other corporations, separated financial firms from groups controlling non-financial companies, extended anti-monopoly law to limit economy-wide concentration of power as well as industry-wide concentration in sales, and limited banks' and other financial institutions' exposure to business groups as well as to individual borrows (Hamdani et al., 2020).

By 2019 , thirteen business groups remained, comprising only $30 \%$ of total market capitalization, and were smaller, simpler, and more industrially focused. However, only part of this decline is directly attributable to the 2013 legal reform. First, the government's refusal to provide bailouts forced financially distressed groups to break up prior to the legal reforms. Second, groups that survived flattened their pyramidal structures to two tiers by merging, rather than shedding, affiliated firms (Hamdani et al., 2020).

This suggests a government policy of not bailing out business groups during economic crises might be as effective in reducing the power of business groups as New Deal-type measures. The US anti-business group reforms occurred amid the Great Depression, so separating the two is difficult. The breakup of Canada's large pyramidal business groups is 
perhaps more informative. These constituted nearly half of the total domestic stock market capitalization in the mid-1980s. As in Israel, the groups were highly diversified and group firms were highly leveraged. A 1990s spike in borrowing costs forced pivotal group firms into bankruptcy and the sales of their control blocks in other group firms. By the turn of the century, only a few small business groups remained. Australian business groups also collapsed for similar reasons; over-leveraged group firms, perhaps combined with ineffective management, saw the groups breaking up after the 1987 stock market crash (Ville, 2018).

Australia, Canada and Israel are all high-income mature democracies, whose media often attacked tight business-government connections as corruption. All three countries also enacted successive corporate governance reforms that curtailed intragroup income and risk shifting and, therefore, group firms' protection from external shocks. Indeed, because many had accumulated high leverage, business group firms were more vulnerable to relatively minor shocks. These countries' histories suggest a less drastic policy change than in the United States or US-occupied Japan. Policy makers wishing to avoid problems with zombie firms and with organ banks might consider forbidding intragroup income and risk shifting, so each group firm is on its own when a shock hits. If group banks can too readily evade such a ban, policymakers might further consider severing banks from business groups as a complementary measure.

\section{CONCLUSION}

In this desperately short chapter, we try to describe how groups containing banks operate differently during economic shocks, depending on whether agency (effective decision-making power) resides in the group bank or not. Illustrative cases arise in the histories of many countries. Different countries provide alternative policy options. Japan provides two archetypical cases that illustrate the economic forces at work.

In late $20^{\text {th }}$ century Japan, banks wielding agency subordinated other group firms, 
imposing creditor-centric corporate governance to suppress risk-taking and minimize default risk, which ultimately preserved low-risk low-productivity zombie firms. This is an adverse selection problem: low productivity firms survived and continued using inputs, workers and capital that more dynamic and innovative firms might have used more productively.

In the 1920s, some Japanese business groups used subservient organ banks to provide long-term preferential debt financing for other group firms. This developed into a moral hazard problem: to serve other group firms, organ banks provided their fellow group firms with more, riskier, and more generous loans than would have been available externally. Income and risk shifting within a group can damp idiosyncratic shocks, and with the help of a group bank, buffer some systemic shocks too. However, when rapid-fire large systemic shocks hit 1920s Japan, all the firms in these groups drew so heavily on their organ banks that depositors and regulators became concerned about organ bank failures. The government declined to bail out the Suzuki group's organ bank, which failed. Its failure left other Suzuki firms without debt refinancing and many ultimately fell into the hands of groups without organ banks. Its failure also destabilized other groups' organ banks, necessitating multiple bank bailouts.

Organ bank failure problems that trigger government bailouts may especially aggravate moral hazard problems. The group shifts risk and losses to its organ bank, which then offloads its risks and losses to the government. Adverse selection arises here too: Even if the organ bank is closed or reopened with new owners, the other group firms not only survive, but have shed losses and risk. Whether the bailed-out organ bank survives with a reduced share price, is relaunched with new owners, or is merged into another bank, the group's controlling entity is little harmed because it has relatively little of its wealth invested in the group bank. And a more loss-free less risky business group can always start another bank or shadow bank.

Perhaps to avoid both classes of problems, some countries' banking legislation 
simply keep banks out of business groups. Canada's successive Bank Acts have mandated that banks be widely held and have no non-financial subsidiaries ().

The U.S. Glass-Steagall Act of 1933, a major New Deal reform, hived the Morgan Bank banks off the Morgan business groups, the country's largest at the time. Turkey, upon bailing out business groups with subservient banks, eventually severed many of those banks from their business groups. However, Korea did the same after bailing out its business groups and banks in 1960, but the business groups repeatedly found ways to establish shadow banks (non-bank firms that were essentially banks) so moral hazard problems recurred. Canada's steadily more binding limitations on tunneling and open-ended prudential regulation making shadow banks readily redesignated as banks, may explain the difference.

Even absent strict and well-enforced regulations limiting risk and income shifting, some groups' controlling entities opt not to use organ banks. This may reflect historical momentum, as with Belgium's Société Générale group and Sweden's Handelsbanken and Wallenberg groups, which grew under the direction of bankers. This may also reflect concepts of "what banks ought to do." Several major early $20^{\text {th }}$ century Japanese business groups' banks followed a "Scottish banking model" - banks ought mainly to provide trade credit, financing purchases and sales of goods collateralized by those goods (Morck \& Nakamura, 2005). Their controlling entities' substantial cash flow rights in their group banks may have made this model attractive. It also excused the family bank from lending to grow firms entrusted to relatives without hurt feelings. When the 1920 s economic shocks toppled the Suzuki group and necessitated bailouts of other organ banks, the Mitsubishi, Mitsui, and Sumitomo groups and their Scottish model banks were far less affected.

Obviously, the problem with relying on banking practice, rather than laws, is that different groups' banks can adopt different practices. Policy-makers wishing to legislate these problems away have several options. 
One policy option is state intervention to break up business groups, as the US did in the 1930s. The tycoons and families controlling large business groups usually have sufficient political influence to make this option unattractive to politicians. The US reforms occurred during the uniquely disastrous Great Depression, for which voters blamed big business. US politicians were perhaps uniquely incentivized to take down business groups. And in US occupied Japan, the business group controlling families had lost all political influence. In general, big business lobbying is powerful and other countries enduring catastrophic downturns did not dismantle business groups. Indeed, business group firms' tight political connections can leave them islands of stability in an otherwise turbulent economy.

An alternative policy option is to condition group bank bailouts on their divorcing their business groups. The government socializes a final round of business group losses amassed in the group banks; but bans group banks thenceforth. This requires preventing groups from establishing organ or shadow banks, which may be difficult for future governments subjected to intense big business lobbying.

A third option is the articulation of Business Group Law that allows piercing the corporate veil in business groups- for example, to give an injured party recourse against the ultimate controlling shareholder or other business group firms (Hopt 2015; Belenzon et al. 2018). While many countries (including the US and UK) have no Business Group Law at all (a business group has no legal definition or standing in court) and treat every corporation as a separate thing).

A fourth policy option, suggested by Australia, Britain, Canada and Israel, is to tighten anti-tunneling provisions over time, in the name of protecting small shareholder, to shut down tunneling. Intragroup transfers of capital, goods and services then must be at external market prices, preventing business group firms from bailing each other out. If no significant advantage then remains for business groups, they often break up.

However, business groups' internal markets for capital, goods and services may be 
socially useful especially where external markets are dysfunctional. Policy makers wishing to safeguard business groups' internal markets are left to choose a lesser evil.

One option is to learn to love group banks, and even organ banks. Business groups span institutional void by allocating goods, services and capital in ways dysfunctional markets cannot. Intragroup capital allocation is an important part of this, so group banks or shadow banks may be important too. If business groups' internal markets promote development enough to justify the attendant distortions, including organ bank failures and bailouts, doing nothing might be defensible.

A second option would mandate that banks have leading roles in business groups, as in postwar Japanese and many European countries. The downside of this option is the survival of zombie firms. Too many of these low-risk low productivity firms, focused on eliminating default risk and keeping earnings above interest costs, can adversely affect economy growth.

Moreover, institutional development makes markets become more efficient and internal business group transactions less socially useful. Development may leave the social costs of business groups outweighing their social benefits (Dau et al. 2021).

\section{REFERENCES}

Aldunate, F., González, F. Prem, M. \& Urzúa, F. (2020). Privatization and business groups: Evidence from the Chicago Boys in Chile. Explorations in Economic History, 78(C) 101355. Allen, F., Carletti, E., Goldstein, I. \& Leonello, A. (2015). Moral hazard and government guarantees in the banking industry. Journal of Financial Regulation 1, no. 1: 30-50.

Becht, M. (2018). Belgium: The disappearance of large diversified business groups. In A. M. Colpan \& T. Hikino, (eds.), Business Groups in the West: Origins, Evolution, and Resilience, Oxford: Oxford University Press.

Belenzon, S., Lee, H. \& Patacconi, A. (2018). Towards a legal theory of the firm: The effects of enterprise liability on asset partitioning, decentralization and corporate group growth. No. w24720. National Bureau of Economic Research.

Bernanke, B. S. (1983). Non-monetary effects of the financial crisis in the propagation of the Great Depression. The American Economic Review, Vol. 73, No. 3: 257-276.

Bertrand, M., Paras M., \& Sendhil M. (2002). Ferreting out tunneling: An application to Indian business groups. The Quarterly Journal of Economics, 117.1: 121-148. 
The Boston Consulting Group. (2012). The power of diversified companies during crises. Bruche, M., \& Llobet, G. (2014). Preventing zombie lending. The Review of Financial Studies, 27.3: 923-956.

Buchuk, D., Larrain, B., Muñoz, F. \& Urzúa, F. (2014). The internal capital markets of business groups: Evidence from intra-group loans. Journal of Financial Economics, 112, no. 2: 190-212. Castaneda, G. (2007). Business groups and internal capital markets: The recovery of the Mexican economy in the aftermath of the 1995 crisis, Industrial and Corporate Change, 16:3: 427-54.

Chernow, R. (1990). The house of Morgan. Touchstone Books.

Choi, Hansoo, Hyoung-Goo Kang, and Changmin Lee. (2018). What Constitutes "Too Big to Jail?" Evidence from South Korea's Family Business Groups." Asia-Pacific Journal of Financial Studies 47.6: 881-919.Chisholm, H. (ed). (1922). Stinnes, Hugo. Encyclopædia Britannica (12th ed.). London \& New York: The Encyclopædia Britannica Company.

Collis, D., Anand, B. \& Cheng J.Y. (2018). The United States in contemporary perspectives: Evolving forms, strategy and performance. In A. M. Colpan \& T. Hikino, (eds.), Business groups in the West: Origins, evolution, and resilience, Oxford: Oxford University Press. Colpan, A.M. \& Hikino, T. (eds.). (2018a). Business groups in the West: Origins, evolution, and resilience, Oxford: Oxford University Press.

Colpan, A. M., \& Hikino, T. (2018b). The evolutionary dynamics of diversified business groups in the West: History and theory. In A. M. Colpan \& T. Hikino, (eds.), Business groups in the West: Origins, evolution, and resilience, Oxford: Oxford University Press.

Colpan, A.M. \& Jones, G. (2013). Vehbi Koç and the making of Turkey's largest business group. Harvard Business School Case 811-081.

Colpan, A. M. \& Jones, G. (2016). Business groups, entrepreneurship and the growth of the Koc Group in Turkey, Business History, 58 (1):69-88.

Constand, R.L. (2003). The supply of trade credit in Japanese firms, Choi, J.J. \& Hiraki, T. (Ed.) The Japanese Finance, (International Finance Review, Vol. 4), Emerald Group Publishing Limited, Bingley, 107-133.

Corsetti, G., Pesenti, P. \& Roubini, N. (1999). What caused the Asian currency and financial crisis?, Japan and the World Economy, 11: 305-373.

Chung, C.Y, Byun J. H., \& Young J. (2019). Corporate political ties and firm value:

Comparative analysis in the Korean Market, Sustainability, 11:327.

Cuervo-Cazurra, A. (2018). Spain: Regulation and ideology as drivers for transformation. In

A. M. Colpan \& T. Hikino, (eds.), Business Groups in the West: Origins, Evolution, and

Resilience, Oxford: Oxford University Press.

Daems, H. (1977). The holding company and corporate control, Boston. MA Springer.

Dau, L., Morck, R., \& Yeung, B. (2021) Business groups and the study of international business: A Coasean synthesis and extension. Journal of International Business Studies 52.2: 161-211.

Demirag, I. \& Serter M. (2003). Ownershup patterns and control in Turkish listed companies. 
Corporate Governance: An International review, 11 (1): 40-51.

Djankov, S., La Porta, R. ,Lopez-de-Silanes, F. \& Shleifer, A. (2008). The law and economics of self-dealing. Journal of Financial Economics, 88, no. 3: 430-465.

Diamond, D., \& Dybvig, P. 1983 Bank runs, liquidity, and deposit insurance. Journal of Political Economy, 91.3: 401-419.

Eisinger, Jesse. (2017) The chickenshit club: Why the justice department fails to prosecute executives. Simon and Schuster.

Faccio, M. (2006). Politically connected firms. American Economic Review, 96.1: 369-386.

Faccio, M., Masulis, R.W. \& McConnell, J.J. (2006). Political connections and corporate bailouts. The Journal of Finance, 61.6: 2597-2635.

Faccio, M., Morck, R. \& Yavuz, M.D. (2021). Business groups and the incorporation of firmspecific shocks into stock prices. Journal of Financial Economics, 139.3: 852-871.

Hamdani, A., Konstantin K. \& Yishay Y. (2021). Regulatory measures to dismantle pyramidal business groups: Evidence from the United States, Japan, Korea and Israel. Hebrew University working paper.

Haber, S. (2013). Crony capitalism and economic growth in Latin America: Theory and evidence. Hoover Institution Press.

Haueter, N.V., \& Jones, G. (2016). Managing risk in reinsurance: from city fires to global warming. Oxford University Press.

Hikino, T. \& Bucheli, M. (2018). The United States in historical perspectives; The strange career of business groups in industrial development. In A. M. Colpan \& T. Hikino, (eds.), Business groups in the West: Origins, evolution, and resilience, Oxford: Oxford University Press.

Hopt, K. (2015). Groups of companies - A comparative study on the economics, law \& regulation of corporate groups. In J. Gordon \& G. Ringe (eds.), Oxford handbook of corporate law \& governance, Oxford University Press.

Hoshi, T., Kashyap, A. \& Scharfstein, D. (1991). Corporate structure, liquidity, and investment: Evidence from Japanese industrial groups, Quarterly Journal of Economics, 106 (1): 33-60.

Johnson, S., La Porta, R., Lopez-de-Silanes,F. \& Shleifer, A. (2000). Tunneling. American Economic Review, 90, no. 2: 22-27.

Jones, G. (2000). Merchants to multinationals. Oxford: Oxford University Press.

Jones, G. \& Colpan, A.M. (2010). Business groups in historical perspectives. In Colpan, A. M., Hikino, T., and Lincoln, J. R. (eds). The Oxford handbook of business groups. Oxford University Press Oxford: Oxford University Press.

Jones, G., \& Wadhwani, D.R. (2007). Entrepreneurial theory and the history of globalization. Business History Conference. Business and Economic History On-line: Papers Presented at the BHC Annual Meeting. Vol. 5. Business History Conference..

Jones, G. (2005). Multinationals and global capitalism: From the nineteenth to the twenty first 
century. Oxford University Press on Demand.

Jones, G. (2012). Banks as multinationals. Routledge..

Jones, G. \& Khanna, T. (2006). Bringing history (back) into international business. Journal of International Business Studies, 37 (4): 453-68.

Kato, T. (1957). Honpo ginkoshiron [History of banks in Japan]. Tokyo: University of Tokyo Press. Kandel, E. Kosenko, K., Morck, R., \& Yafeh. Y. (2019). The great pyramids of America: A revised history of US business groups, corporate ownership, and regulation, 1926-1950. Strategic Management Journal, 40(5): 781-808.

Khanna, T. \& Yafeh, Y. (2007). Business groups in emerging markets: Paragons or parasites? Journal of Economic Literature, XLV: 331-72.

Kindleberger, C. P. (1978). Manias, panics, and crashes; A history of financial crises. Basic. Koc, V. (1983). Hayat hikayem, Istanbul: Otokoc.

Krueger, A. O. (1974). The political economy of the rent-seeking society. The American Economic Review, 64.3: 291-303.

Kuppuswamy, V. \& Villalonga, B. (2010). Does diversification create value in the presence of external financing constraints? Evidence from the 2007-2009 financial crisis, Harvard Business School Working Paper No. 10-101.

La Porta, R., Lopez-de-Silanes, F. \& Shleifer, A. (1999). Corporate ownership around the world. The journal of finance, 54.2: 471-517.

La Porta, R., Lopez-de-Silanes, F. \& Zamarripa, G. (2003). Related lending. The quarterly Journal of Economics, 118.1: 231-268.

Laeven, L., \& Levine, R. (2009). Bank governance, regulation and risk taking. Journal of Financial Economics, 93.2: 259-275.

Larsson, M. \& Petersson, T. (2018). Sweden: Tradition and renewal. In A. M. Colpan \& T. Hikino, (eds.), Business groups in the West: Origins, evolution, and resilience, Oxford: Oxford University Press.

Lebovics, H. (1969). Social conservatism and the middle class in Germany, 1914-1933, NJ: Princeton University Press.

Lefort, F. (2010). Business groups in Chile. In Colpan, A. M., Hikino, T., and Lincoln, J. R. (eds). The Oxford handbook of business groups. Oxford University Press Oxford: Oxford University Press.

Lynn, L. H., \& Rao, H. (1995). Failures of intermediate forms: A study of the Suzuki Zaibatsu. Organization Studies, 16.1: 55-80.

Manos, R., Murinde, V. \& Green, C.J. (2007). Leverage and business groups: Evidence from Indian firms. Journal of Economics and Business 59.5 : 443-465.

Morck, R. (2005). How to eliminate pyramidal business groups: the double taxation of intercorporate dividends and other incisive uses of tax policy. Tax policy and the economy 19: 135-179. 
Morck, R., \& Yeung, B. (2004). Family control and the rent-seeking society. Entrepreneurship Theory and Practice 28.4: 391-409.

Morck, R. \& Nakamura M. (1999). Banks and corporate control in Japan. Journal of Finance, 54 (1): 319-339.

Morck, R., Nakamura, M. \& Shivdasani, A. (2000). Banks, ownership structure, and firm value in Japan. The Journal of Business 73.4: 539-567.

Morck, R. \& Nakamura, M. (2005). A frog in a well knows nothing of the ocean: A

history of corporate ownership in Japan. In Morck, R. (Ed). A history of corporate governance around the world: Family business groups to professional managers, University of Chicago Press.

Morck, R., Yavuz, M. D. \& Yeung, B. (2011). Banking system control, capital allocation, and economy performance. Journal of Financial Economics, 100.2: 264-283.

New York Times. (1939). 22,000 Nazis hold rally in garden - Police check foes, New York Times, February 21, 1939: 1 \& 5.

New York Times. (1936). 18,000 honor Lenin in garden program, New York Times, January 21, 1936: 4.

Noiseux, M. H. 2002. Canadian bank mergers, rescues and failures. Doctoral Thesis. Concordia University

North, D. C., Wallis, J. J., Webb, S. B., \& Weingast, B. R. (eds.). (2013). In the shadow of violence: Politics, economics, and the problems of development. Cambridge University Press.

Oh, J.K. (1999). Korean Politics: The Quest for Democratization and Economic Development, Ithaca and London: Cornell University Press.

Okazaki, T. \& Yokoyama, K. (2001). Governance and performance of banks in prewar Japan: Testing the" organ bank" hypothesis quantitatively, University of Tokyo, Faculty of Economics, Discussion Paper CIRJE-F-111, April (2001).

Oprisk dergisi. (2014). Imarbankasi'nin iflasi ve 7.5 milyar TL zarar.

Pascale, R. \& Rohlen T.P. (1983). The Mazda turnaround, Journal of Japanese Studies, 9: 21964.

Ricardo J. C., Hoshi, T. \& Kashyap, A.K. (2008). Zombie lending and depressed restructuring in Japan, American Economic Review, 98 (5): 1943-1977

Schneider, B.R. (2010). Business groups and the State: The politics of expansion, restructuring, and collapse. In A. M. Colpan, T. Hikino \& J. R. Lincoln (eds.), Oxford handbook of business groups, Oxford: Oxford University Press Oxford: Oxford University Press.

Roll, R. (1988). Presidential address: R2. Journal of Finance. 43.2 (1988): 51-566.

Schroter, H. (2018). Germany: An engine of modern economic development. In A. M. Colpan \& T. Hikino, (eds.), Business groups in the West: Origins, evolution, and resilience, Oxford: Oxford University Press.

Shizume, M. (2009). The Japanese economy during the interwar period: Instability in the 
financial system and the impact of the world depression, Bank of Japan Review, Bank of Japan, 2009-E-2.

Silva, A. F. \& Neves P. (2018). Portugal: Changing environment and flexible adaptation. In A. M. Colpan \& T. Hikino, (eds.), Business groups in the West: Origins, evolution, and resilience, Oxford: Oxford University Press.

Strouse, J. (2012). Morgan: American financier. Random House.

Sjögren, H. (1991). Long term contracts in the Swedish bank-orientated financial system during the inter-war period. Business History, 33.3: 119-137.

Strangeland, D., Daniels, R. J.\& Morck, R. (1995). In high gear: A case study of the Hees-Edper corporate group. In R.J. Daniels \& R. Morck (eds.), Corporate decision making in Canada, 223-240.

Ville, S. (2018). Australia: From Family Networks to Boom \& Bust Groups. In A. M. Colpan \& T. Hikino (Eds.), Business Groups in the West: The Evolutionary Dynamics of Big Business: chapter 16. Oxford University Press. 